\title{
Partitioning of soil water among canopy trees during a soil desiccation period in a temperate mixed forest
}

\author{
M. Meißner ${ }^{1}$, M. Köhler ${ }^{1}$, L. Schwendenmann ${ }^{2}$, and D. Hölscher ${ }^{1}$ \\ ${ }^{1}$ Department of Tropical Silviculture and Forest Ecology, Burckhardt Institute, Faculty of Forest Sciences and Forest Ecology, \\ University of Göttingen, 37077 Göttingen, Germany \\ ${ }^{2}$ School of Environment, The University of Auckland, Auckland 1142, New Zealand
}

Correspondence to: M. Meißner (mmeissn3@gwdg.de)

Received: 12 March 2012 - Published in Biogeosciences Discuss.: 9 May 2012

Revised: 27 July 2012 - Accepted: 4 August 2012 - Published: 30 August 2012

\begin{abstract}
Complementary resource use is considered an important mechanism in the study of biodiversity effects. Here we explore how species identity, species mixture and tree size influence the vertical partitioning of soil water among canopy trees during a soil desiccation period. In the Hainich Forest, Germany, the species Fagus sylvatica, Tilia sp. and Fraxinus excelsior were studied in single- and three-species mixed clusters, each consisting of three co-dominant trees situated within a larger mixed forest stand. Vertical soil water uptake depth was assessed by analyzing the hydrogen stable isotope composition (deuterium, $\delta \mathrm{D}$ ) of water from depth intervals throughout the soil profile and in tree xylem water. For single species clusters, a mixing model suggested that Fagus distinctively drew water from soil depths of $0.3-0.5 \mathrm{~m}$, Tilia from $0.3-0.5 \mathrm{~m}$ and $0.5-0.7 \mathrm{~m}$ and Fraxinus mainly used water from $0.5-0.7 \mathrm{~m}$. In mixed clusters, the uptake patterns of Fagus and Tilia were similar to those of the singlespecies clusters (mainly uptake form $0.3-0.5 \mathrm{~m}$ ), but Fraxinus showed a different uptake pattern. Fraxinus in mixture had a somewhat homogenously distributed uptake over the soil depths $0.2-0.7 \mathrm{~m}$. For single species clusters, there was no correlation between main soil water uptake depth and tree diameter, irrespective of variations in tree size. In contrast, for mixed clusters there was a significant decrease in the main uptake depth with increasing tree size $(P<0.001$, $\left.R_{\text {adj }}^{2}=0.73\right)$, irrespective of species mix. In consequence, soil water partitioning was strongest where species were mixed and tree size varied. We further analyzed whether single and mixed-species clusters differed in the level of water uptake, e.g. due to complementarity, but our soil water budgeting did not indicate any such differences. A possible explanation
\end{abstract}

might be that the volume of water used is predominantly governed by properties at the stand level, such as aerodynamic roughness, rather than by processes acting at the meter scale between neighbouring trees. With respect to application, we assume that the upcoming close-to-nature forestry approach for the area, which fosters mixed stands of heterogonous diameters, may result in enhanced complementarity in soil water uptake among canopy trees.

\section{Introduction}

Water availability is considered a major control of productivity in forests of Central Europe and other regions of the world (Breckle and Walter, 2002; Huxman et al., 2004; Ellenberg and Leuschner, 2010). Under certain environmental conditions, the degree to which water is available for transpiration and production is governed by a plant's capacity to exploit soil water resources - a property that can be enhanced by complementarity among co-occurring plants. Resource use complementarity postulates that functional traits enable plants to exploit resources unavailable to others or use the same resource at a different place or time (Vandermeer, 1989). Resource partitioning and the consequently more effective utilization of resources have been suggested as an explanation for the higher productivity observed in many mixed plant communities compared to monospecific stands (Haggar and Ewel, 1997; Hooper et al., 2005).

One approach to studying plant water acquisition patterns and complementary water use is the assessment of water stable isotopes such as deuterium in soil and plants (Ehleringer 
and Dawson, 1992). Since roots do not fractionate water during uptake, the deuterium signatures in the plant water reflect the uptake-weighted average of $\delta \mathrm{D}$ of potential water sources (Ehleringer and Dawson, 1992). A comparison of plant water $\delta \mathrm{D}$ with that of soil water from different soil depths can reveal the actual soil water source depth for any plant.

By using such an approach in a diverse Panamanian old-growth forest, considerable spatial soil water partitioning among co-existing trees was documented (Jackson et al., 1995; Meinzer et al., 1999). Within and among species, water uptake depth was strongly related to tree size, with smaller trees preferentially tapping deeper sources of soil water than larger trees; species-specific characteristics were however difficult to disentangle (Meinzer et al., 1999). Species-specific soil water uptake patterns were found in a study on Indonesian cacao agroforests. Cacao trees mainly took up water from upper soil layers, whereas the associated Gliricidia shade trees acquired soil water mainly from deeper soil layers (Schwendenmann et al., 2010); however, the shade trees tapping deeper water sources were considerably higher and had a greater diameter than that of the cacao trees.

In grasslands as well as tree plantations, it has been observed that plant species diversity enhanced transpiration rates (Verheyen et al., 2008; Kunert et al., 2012) and, complementarity with respect to water uptake, was discussed as an underlying mechanism. Such a strategy may however also lead to a faster decline in available water for diverse plant species communities during drought (Van Peer et al., 2004; Verheyen et al., 2008). There is little information on complementarity in relation to water uptake in temperate broadleaved mixed forests, but such information is becoming more relevant as there is an ongoing trend in silviculture towards more naturalness or close-to-nature forestry (O'Hara, 2001; LÖWE, 2007). Close-to-nature forestry implies a transformation of monocultural stands of narrow tree diameter range into stands composed of several tree species with a broader range of diameter. Since global climate change scenarios predict an increase in intensity and frequency of drought events during the vegetation period for large parts of Central Europe (Rowell and Jones, 2006; Christensen et al., 2007), there is an increasing urgency to study possible effects of changing species composition and tree diameter range on soil water use.

The present study was conducted in the temperate broadleaved Hainich Forest of central Germany. Previous studies from the region indicate considerable differences in water vapour exchange at the leaf level (Gebauer et al., 2008) as well as whole-tree water use among co-occurring tree species (Köcher et al., 2009). At the stand level, there were indications of enhanced soil water uptake during periods when soil water content declined in mixed stands compared to monospecific beech stands (Krämer and Hölscher, 2010). In this study, we focused on groups of neighbouring trees (tree clusters), as neighbourhood was suggested to be highly important in diversity studies (Potvin and Dutilleul, 2009), and particularly important for the assessment of complementarity. Our hypotheses were therefore as follows: during summer soil desiccation, (1) tree species differ in vertical soil water uptake patterns; (2) in mixed-species clusters there is complementarity in soil water uptake; and (3) across all trees studied, the depth of soil water uptake scales with tree size. We further asked whether differences in water uptake volumes occur among the differently composed tree clusters.

\section{Methods}

\subsection{Study area}

This study was conducted in the Hainich Forest in northern Thuringia, central Germany, an area rich in tree species. The study plots are located in the south-eastern part of the forest area on a low mountain range at an elevation of approximately $350 \mathrm{~m}$ (a.s.l.). The geological substrate is Triassic limestone covered by loess, forming nutrient-rich Luvisols (Guckland et al., 2009). The climate is subatlantic with a mean annual temperature of $7.5^{\circ} \mathrm{C}$ and a long term mean precipitation of approximately $590 \mathrm{~mm}$ (Deutscher Wetterdienst, Offenbach, Germany, 1973-2004). For the last $40 \mathrm{yr}$, the forest has remained almost free of harvesting or thinning due to its use as a military training area since 1964 and its integration into a new national park in 1997 (Mölder et al., 2006). The forest stands in which our study clusters are located may contain deciduous forest over $200 \mathrm{yr}$ old (Mölder et al., 2009). The dominant tree species are Fagus sylvatica (L.), Fraxinus excelsior (L.), Tilia cordata (Mill.) and Tilia platyphyllos (Scop.). The two Tilia species often form hybrids, which are phenologically difficult to differentiate. Hence, in this study we did not differentiate between the species and refer to them as Tilia sp.

\subsection{Tree clusters}

In two mixed forest stands within the Hainich (Lindig and Thiemsburg, approx. $2 \mathrm{~km}$ apart), the species Fagus sylvatica, Tilia sp. and Fraxinus excelsior, were studied in single and three-species mixed clusters. Clusters consisted of three co-dominant trees and each cluster type was replicated four times, resulting in a total of 16 clusters ( 8 in each area). The average distance between the clusters of each area was $124 \mathrm{~m}$ at Thiemsburg and $112 \mathrm{~m}$ at Lindig. There were no significant differences among cluster types with respect to tree height, but the monospecific Fagus clusters showed significantly larger stem diameter at breast height (dbh) than the monospecific Fraxinus clusters (Table 1).

A Shannon-Wiener diversity index $\left(\mathrm{H}^{\prime}\right)$ of trees within a $20 \mathrm{~m}$ radius of the clusters did not reveal any significant differences among cluster types. Soil clay content and bulk density increased with increasing soil depth, comparably within all clusters (Table A1). 
Table 1. Characteristics of single and mixed species tree clusters. Values are means \pm sd $(n=4)$; similar letters specify no significant difference between cluster types. The Shannon biodiversity index $\left(\mathrm{H}^{\prime}\right)$ refers to a $20 \mathrm{~m}$ radius around the center of each cluster.

\begin{tabular}{lrrrr}
\hline & \multicolumn{4}{c}{ Cluster } \\
& Fagus & Tilia & Fraxinus & Mixed \\
\hline Tree dbh $(\mathrm{cm})$ & $54.4 \pm 12_{\mathrm{a}}$ & $44.1 \pm 14.3_{\mathrm{ab}}$ & $30.2 \pm 3.7_{\mathrm{b}}$ & $39.7 \pm 8.1_{\mathrm{ab}}$ \\
Tree height $(\mathrm{m})$ & $28.6 \pm 2.8_{\mathrm{a}}$ & $27.9 \pm 2.5_{\mathrm{a}}$ & $29.9 \pm 1.1_{\mathrm{a}}$ & $28.4 \pm 2.2_{\mathrm{a}}$ \\
Cluster area $\left(\mathrm{m}^{2}\right)$ & $33.3 \pm 14.6_{\mathrm{a}}$ & $27.1 \pm 18.8_{\mathrm{a}}$ & $7.8 \pm 1.6_{\mathrm{a}}$ & $21.7 \pm 21.4_{\mathrm{a}}$ \\
Shannon $\mathrm{H}^{\prime}$ & $0.8 \pm 0.3_{\mathrm{a}}$ & $1.0 \pm 0.1_{\mathrm{a}}$ & $1.2 \pm 0.3_{\mathrm{a}}$ & $1.2 \pm 0.2 \mathrm{a}$ \\
\hline
\end{tabular}

\subsection{Soil moisture measurements}

Soil volumetric water content $\left(\theta\right.$ in $\left.\mathrm{m}^{3} \mathrm{~m}^{-3}\right)$ was measured with a portable FDR probe (Frequency Domain Reflectometry; Diviner 2000, Sentek Pty Ltd., Stepney, Australia). Four PVC access tubes were installed on each cluster (Fig. 1) to a maximum depth of $0.7 \mathrm{~m}$ and readings were taken at depth intervals of $0.1 \mathrm{~m}$ at an average distance of $3.4 \pm 1.5 \mathrm{~m}$ from the clustered trees. In some clusters, it was not possible to install all access tubes to the full extent, as heterogeneously weathered limestone debris occurred already at shallow depths and obstructed the installation. The FDR sensor was depth-specifically calibrated for the local soil conditions (Krämer and Hölscher, 2010). Data on soil water content were collected weekly from 30 April to 31 October 2009.

Soil water potentials ( $\psi$ in $\mathrm{hPa}$ ) were measured with tensiometers (T1-UMS, Umwelt Monitoring Systeme, Germany) at depths of $0.1,0.3$ and $0.5 \mathrm{~m}$. The tensiometers used had a measurement limit of $-700 \mathrm{hPa}$, which resulted in them drying-out during prolonged desiccation periods. To compensate for this effect we used the Rosetta DLL (Dynamik Linked Library) program by Schaap et al. (2001), implemented in the HYDRUS-1D model (Simunek et al., 2008), to transform measured volumetric soil water contents into soil water potentials. Measured water potentials from tensiometers were used as inputs for the model calculation, as were soil bulk density, sand, silt and clay content (Table A1). Calculated values were used when water potentials fell below the minimum measurement threshold of the tensiometers.

\subsection{Soil water uptake depth}

To assess profiles of relative water uptake for each of the observed species, we determined the natural abundance of the stable isotope ${ }^{2} H=$ Deuterium, D. Samples from soil and trees of the 16 clusters were taken once during a summer desiccation period on 25 and 26 August in 2009 (Fig. 2).

Soil samples were taken at depth intervals of $0-0.1$, $0.1-0.2,0.2-0.3,0.3-0.5 \mathrm{~m}$ and $0.5-0.7 \mathrm{~m}$ under the crown area inside the clusters. Each sample consisted of a mixture of two adjacent soil cores taken at the same depth. Xylem tissue samples were taken from the outer $6 \mathrm{~cm}$ of the stem

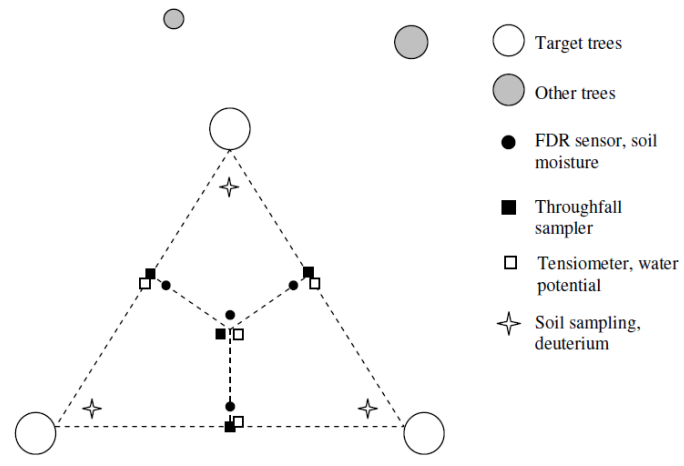

Fig. 1. Schematic study plot design (tree cluster) with measurement locations.

at three points at breast height from each individual tree with an increment borer. The bark was removed after sampling to avoid contamination of xylem water with phloem water. All samples were stored in $40 \mathrm{ml}$ glass bottles, closed with a Teflon coated lid, sealed with Parafilm, and then kept frozen until water extraction to reduce subsequent evaporation from the samples (Ehleringer et al., 2000). Extraction of water from plant and soil samples was conducted via cryogenic vacuum extraction according to Ehleringer and Osmond (1989). The applied extraction time was $90 \mathrm{~min}$ for soil and stem samples (West et al., 2006).

The analysis of extracted water was carried out at the Center for Stable Isotope Research and Analysis (KOSI, GeorgAugust-University Göttingen, Germany). Measurements of the hydrogen isotopic composition were conducted by injecting the water into a high temperature conversion elemental analyzer (TC/EA, Thermo Electron Corporation, Bremen, Germany) coupled via a Con-Flo III interface to a Delta V Plus isotope ratio mass spectrometer (Thermo Electron Corporation) (Gehre et al., 2004). Isotope ratios were expressed as per mill deviations to the internationally accepted Vienna Standard Mean Ocean Water (VSMOW, $R_{\text {Standard }}$ ) (Gonfiantini, 1978) with a measurement precision of $\pm 2 \%$ o for $\delta \mathrm{D}$.

In order to identify the depth of water uptake for plants, many studies have utilized the direct inference method by comparing the plant signatures with the isotopic gradients in the soil profiles and assuming that plants are obtaining water mainly from one soil depth. However, this visual method precludes the possibility of assessing proportional contributions of multiple water sources by quantitative means (Asbjornsen et al., 2007). Therefore, we used a mixing model (Isosource, Phillips and Gregg, 2003) that calculates the relative contribution of each soil depth to stem water in order to assess the soil depth each tree used as a potential water source. The underlying assumption is that the isotopic signature of the plant water is a mixture of the signatures found in the soil. In their 

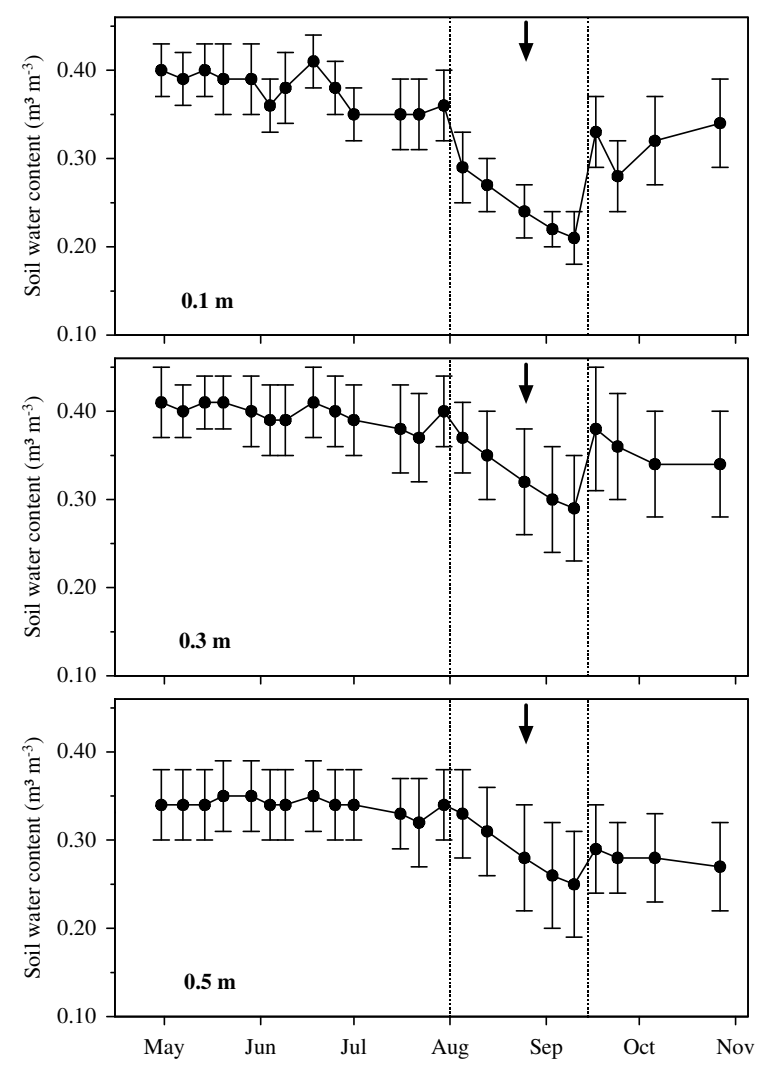

Fig. 2. Volumetric soil water content at $0.1,0.3$ and $0.5 \mathrm{~m}$ soil depth for the tree clusters during the study period in 2009. Values are means $\pm \mathrm{sd}(n=16)$. Dotted lines indicate the time frame for which soil water budgeting was conducted; arrows mark the time when soil and tree samples were taken for deuterium analysis.

study, Asbjornsen et al. (2007) showed that this model can reveal subtle differences in water uptake patterns that are not apparent through visual assessment alone. The fractional increment used in our model calculations was set to $1 \%$ and the tolerance to $0.5 \%$. It has to be noted that the mixing model outcome showed a range of feasible source contributions for a given soil layer. For statistical analyses the mean of all feasible source contribution estimates (mean model outcome) for a given soil layer was used. In order to relate tree dbh to main soil water uptake depth, we also plotted the isotope signature $(\delta \mathrm{D})$ of each tree's main water uptake depth against its respective dbh.

\subsection{Soil water budgeting}

In order to determine the daily water uptake per tree cluster $W u,\left(\mathrm{~mm} \mathrm{day}^{-1}\right)$ during the soil desiccation period in 2009 (30 July to 9 October 2009), soil water budgeting was conducted at $0-0.7 \mathrm{~m}$ soil depth for each cluster Eq. (1). Average throughfall on all clusters during that period was $8.1 \mathrm{~mm}$. Soil water storage was calculated for each cluster from soil water content $\left(\mathrm{m}^{3} \mathrm{~m}^{-3}\right)$ multiplied by the depth of each soil layer $(0.1 \mathrm{~m})$.

$W u=\frac{(T f+S f)-\Delta S}{\Delta t}$

Variables included in the budgeting equation were throughfall $(T f)$, stemflow $(S f)$, change in soil water storage between two successional measurements $(\Delta S)$ and the elapsed time between two successional measurements $(\Delta t)$. Runoff and deep drainage can be neglected in our case due to the level terrain and low soil water content during the desiccation period. According to a modelling study by Bittner et al. (2010), for these forests stands drainage can be considered zero during summer months and particularly so during dry spells.

Stemflow was estimated from data for the same forest area taken from the study of Krämer and Hölscher (2009). For each cluster tree, we used the available data on stemflow in relation to dbh and rainfall intensity to calculate total inflow of stemflow per cluster and rainfall event. However, its quantity was of comparatively little importance $(0-3 \%$ of gross precipitation), even for Fagus. We measured throughfall at four positions on each cluster. The throughfall gauges consisted of a plastic bottle screwed to a funnel with an opening of $10.5 \mathrm{~cm}$ in diameter. The bottle was housed in a plastic tube attached to a metal rod at a height of one meter. To reduce evaporation from the rain gauge, a table tennis ball was placed in the funnel. Gauges were emptied weekly from 30 April to 31 October 2009.

\subsection{Data analysis}

For every sampling date, mean values and standard deviation of rainfall, soil water content and soil water tension were calculated for each cluster $(n=4)$. Before analysis, parameters were tested for normality using the Shapiro-Wilks test. We applied a linear mixed effect model to identify effects of tree species and soil depth on fractional water uptake. An ANOVA was applied on the model outcome for variance analysis followed by a post-hoc HSD-test for pair wise comparison and correlation analysis. The model output suggested that the explanatory variables soil depth and the soil depth by species interaction had significant effects in the single species clusters as well as in the mixture $(p<0.001)$. For species difference in terms of amounts of daily water uptake and throughfall, ANOVA and HSD-test analysis were conducted too. All analyses were carried out using R, version 2.11.1 (R Development Core Team, 2010). 


\section{Results}

\subsection{Soil water uptake depth}

At the time of sampling, the soil water isotopic signature for $\delta \mathrm{D}$ showed a decline in the soil profile from the topsoil to $0.5 \mathrm{~m}$, levelling off at $0.5-0.7 \mathrm{~m}$ (Fig. 3a), most likely due to the isotope fractionation caused by evaporation. Isotopic gradients of $\delta \mathrm{D}$ in the soil profiles were comparable among the different species in single-species and in mixed clusters (Fig. A1). Figure A1 shows that stem water $\delta \mathrm{D}$ matched soil water $\delta \mathrm{D}$ in deeper layers $0.3-0.5 \mathrm{~m}$ and $0.5-0.7 \mathrm{~m}$, depending on species and mixture. Soil water potentials $(\Psi)$ in the clusters increased from an average of $\sim-1200 \mathrm{hPa}$ in $0-0.1 \mathrm{~m}$ to $\sim-600 \mathrm{hPa}$ in $0.1-0.2 \mathrm{~m}$, followed by a mellower increase to $\sim-230 \mathrm{hPa}$ in $0.5-0.7 \mathrm{~m}$ soil depth (Fig. 3b).

The patterns shown in Fig. 3 resulted in a strong relationship between soil water $\delta \mathrm{D}$ and $\Psi ; \delta \mathrm{D}$ decreased with increasing $\Psi$ (Fig. 4).

The mixing model indicated that in single-species clusters, Fagus obtained water mainly from $0.3-0.5 \mathrm{~m}$, and that Tilia utilized the soil depth range of $0.3-0.5 \mathrm{~m}$ and $0.5-0.7 \mathrm{~m}$ to a similar extent. Fraxinus largely drew water from $0.5-0.7 \mathrm{~m}$ soil depth, which differed significantly from the other species (Fig. 5a).

In mixed clusters, Fagus and Tilia mainly took water from $0.3-0.5 \mathrm{~m}$. Fraxinus showed a wider range of water uptake by also tapping water sources from $0.2-0.3 \mathrm{~m}$ depth but taking a lower fraction from $0.5-0.7 \mathrm{~m}$ soil depth (Fig. $5 \mathrm{~b}$ ). The significant difference in water uptake for Fraxinus compared to the other species was a lower uptake fraction from $0.3-0.5 \mathrm{~m}$.

A comparison of fractional water uptake between species in single and mixed species clusters showed significant differences at the depth intervals $0.3-0.5 \mathrm{~m}$ and $0.5-0.7 \mathrm{~m}$ for Tilia and at $0.5-0.7 \mathrm{~m}$ for Fraxinus, while the pattern of $\mathrm{Fa}$ gus showed no such difference. In single species clusters compared to mixed clusters, Tilia drew significantly less water from $0.3-0.5 \mathrm{~m}$ depth and more from $0.5-0.7 \mathrm{~m}$, and Fraxinus drew less water from $0.5-0.7 \mathrm{~m}$ in admixture with other species.

In the single-species clusters, there was no clear relation between tree diameter and deuterium signature of the main soil water uptake depths despite a considerable diameter range $(38.1-72.2 \mathrm{~cm}$ for Fagus, $23.6-70.3 \mathrm{~cm}$ for Tilia and $22.3-38.6 \mathrm{~cm}$ for Fraxinus) (Fig. 6a-c). In contrast, in the mixed clusters (dbh ranging from 24.0-56.1 and no species dominating a certain diameter range), $\delta \mathrm{D}$ of the main uptake depth increased significantly with increasing $\operatorname{dbh}\left(p<0.001 ; R_{\text {adj }}^{2}=0.73\right.$; Fig. 6d).

This suggests that in the mixed clusters, trees with large dbh obtained water mainly from $0.3 \mathrm{~m}$ and above, whereas trees with a smaller dbh mainly tapped the soil layers below $0.3 \mathrm{~m}$.

\subsection{Volume of soil water uptake}

The computed average daily water uptake during the soil desiccation period (from 30 July 2009 to 10 September 2009) for the single-species clusters was $2.6 \pm 0.4 \mathrm{~mm} \mathrm{~d}^{-1}$ for $\mathrm{Fa}$ gus, $2.9 \pm 0.5 \mathrm{~mm} \mathrm{~d}^{-1}$ for Tilia, $3.0 \pm 0.5 \mathrm{~mm} \mathrm{~d}^{-1}$ for Fraxinus; for the mixed species clusters it was $2.8 \pm 0.4 \mathrm{~mm} \mathrm{~d}^{-1}$. There were no significant differences in average daily water uptake between the four cluster types (Fig. 7).

\section{Discussion}

\subsection{Water uptake depth}

The samples for the deuterium analysis were taken during a summer period when soil water content declined, as it frequently occurs in the region as, e.g. documented in Hölscher et al. (2005) and Krämer and Hölscher (2010). At the time of sampling, a gradient in soil water $\delta \mathrm{D}$ signatures had established that accordingly allowed for a differentiation of soil depth. The lowest $\delta \mathrm{D}$ signatures (more negative) were found at greater soil depths where the soil water potential was also highest (less negative). Due to the water potential gradient, it can be assumed that with increasing soil depth water, extraction became easier for the trees. A study on fine root distribution conducted in 12 nearby study plots and on the same tree species found that fine root biomass decreased markedly with soil depth, with $\sim 64-77 \%$ being located in the upper $0.2 \mathrm{~m}$ of the soil profile, independent of tree species or species mixture (Meinen et al., 2009a). Therefore, we can assume a comparable root distribution for our tree clusters and species, with a higher fine root allocation in shallow layers and less in the deeper ones.

The comparison of xylem and soil water $\delta \mathrm{D}$ values indicated differences in water uptake patterns of the three studied species of canopy trees growing in single species clusters. It revealed a significantly higher water uptake at the depth interval of $0.3-0.5 \mathrm{~m}$ for Fagus clusters and at 0.5$0.7 \mathrm{~m}$ also a higher uptake for Fraxinus clusters, compared to the other species, respectively (Fig. 5a). From such data, one may be expected to find water uptake complementarity where these species occur in mixtures due to differing main water uptake depths. In mixed clusters, Fraxinus showed a distinctly lower water uptake from $0.3-0.5 \mathrm{~m}$ soil depth and again a higher uptake from $0.5-0.7 \mathrm{~m}$ compared to the other two species (Fig. 5b). The assumed complementarity from the single cluster observation was not confirmed in the mixture, as Fagus and Tilia appear to draw water from the exact same depth $(0.3-0.5 \mathrm{~m})$ and Fraxinus shows a different water uptake pattern.

A comparison between single and mixed clusters showed that Tilia and Fraxinus seemed to have a markedly different water uptake pattern when growing in a mixture with other species, while the uptake pattern of Fagus 

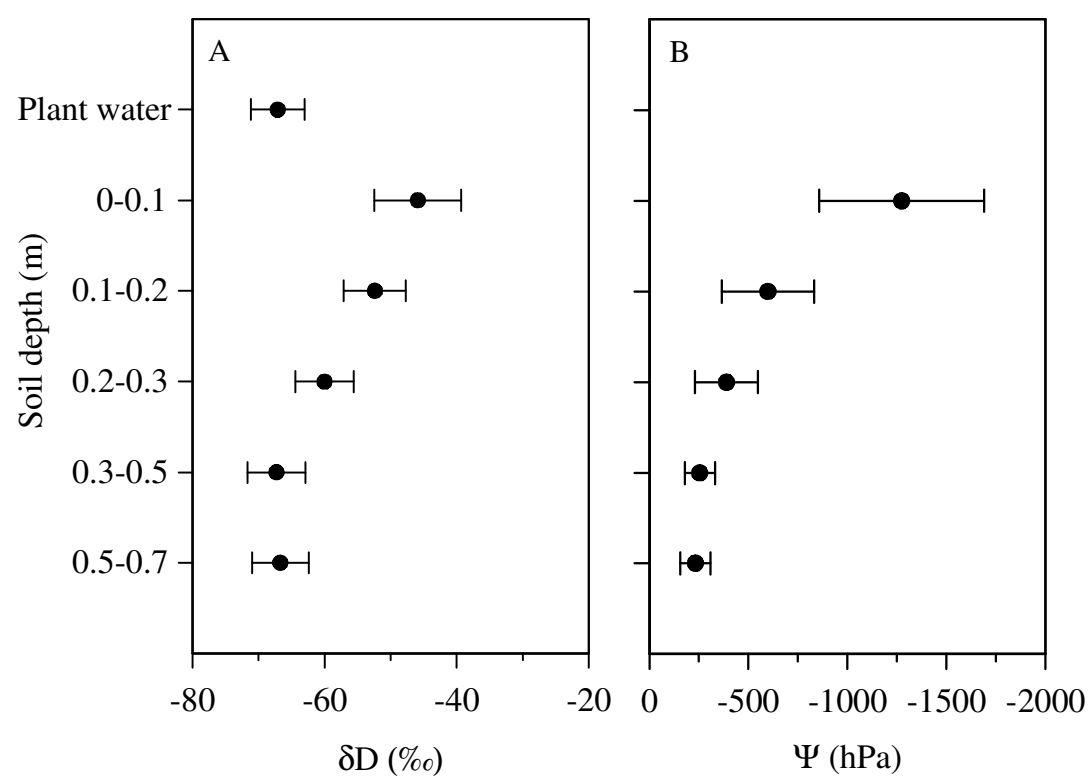

Fig. 3. Isotopic signatures, $\delta \mathrm{D}(\% \circ)$ of plant and soil water of the tree clusters $(\mathbf{A})$ and corresponding soil water potentials $(\mathbf{B})$. Values are means $\pm \mathrm{sd}(n=16)$.

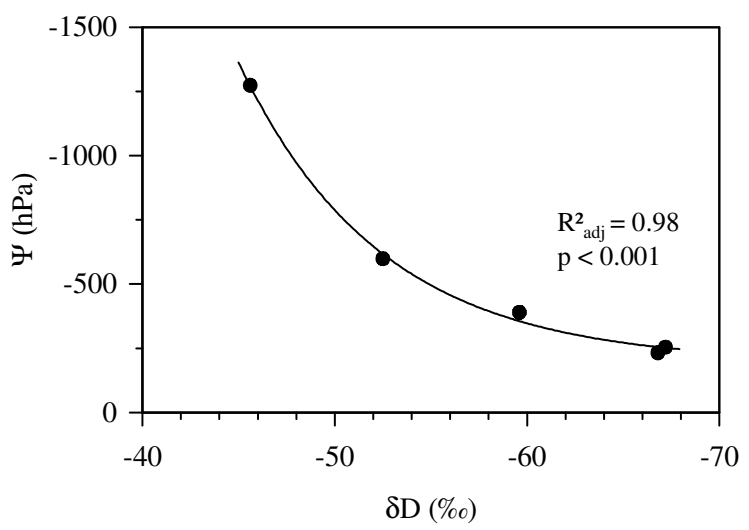

Fig. 4. Relationship between soil water potential and soil water $\delta \mathrm{D}$ for the data shown in Fig. 3.

remained independent of admixture. Fagus is usually considered a highly competitive species in Central European forests, which is mainly attributed to the well developed ability of mature trees to cast shade that constricts the development of many other tree species, and considering its own offspring are shade tolerant (Ellenberg and Leuschner, 2010). Moreover, in the rhizosphere, Fagus was documented to be a strong competitor (Leuschner et al., 2001; Rewald and Leuschner, 2009; Meinen et al., 2009a, b). Thus, it is possible that competition with Fagus in mixed clusters led to changes in uptake patterns of Tilia and Fraxinus.

Complementarity in soil water uptake among species was mainly related to the difference in soil water uptake depth between Fraxinus and the other two species, and it was ob- served in both single- and in mixed species clusters. The water uptake of Fraxinus differed by one and two soil depth intervals in the single and mixed species clusters, respectively. However, in both situations it only withdrew approximately $70 \%$ of its water from the given depths, which suggests that the water uptake pattern of Fraxinus was flexible, but that the share of soil water uptake from soil depths with little interference from other species was similar in both situations. Interestingly, Fraxinus rarely occurs in Central European forests as a mature tree in single-species stands, while it is frequently found in mixed forests with neighbours belonging to other tree species. In the mixed clusters we found a strong relationship between $\delta \mathrm{D}$ signature of the main water uptake depth and dbh $\left(R_{\text {adj }}^{2}=0.73, p<0.001\right)$. Trees with larger dbh obtained water predominantly from the topsoil, whereas trees with smaller dbh mainly tapped the soil layers below. A similar pattern with smaller trees tapping at deeper sources of water than larger ones was found by Meinzer et al. (1999) in a tropical old-growth forest in Panama. The authors suggested that large trees have a more extended horizontal root system, allowing for partial compensation of the reduced water content in upper soil layers with a more extensively explored horizontal soil area. Such an explanation would fit with the finding of Lang et al. (2010) in our study area who found that $\mathrm{dbh}$ is positively correlated with root distance from the tree. A higher soil nutrient content is also often found in the upper soil layers, making it beneficial for trees with large dbh to utilize these soil regions, as their demand on nutrients is higher when compared to smaller trees.

Meinzer et al. (1999) further mention that diurnal stem water storage capacity increases exponentially with stem size, 
Fagus

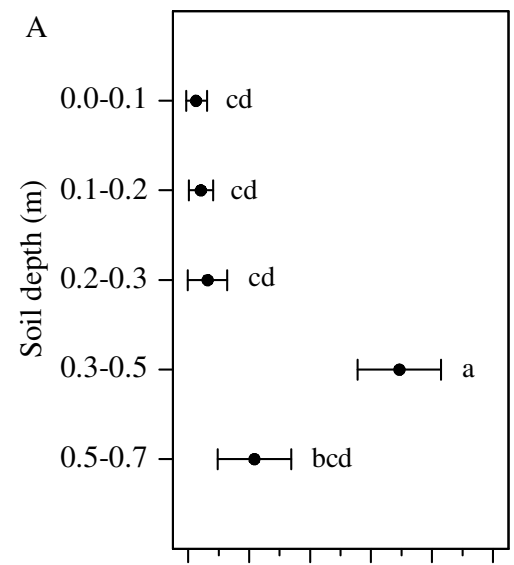

B

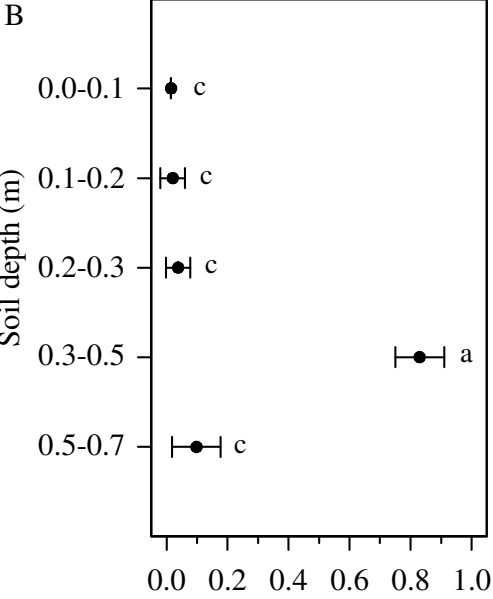

Fractional water uptake
Tilia
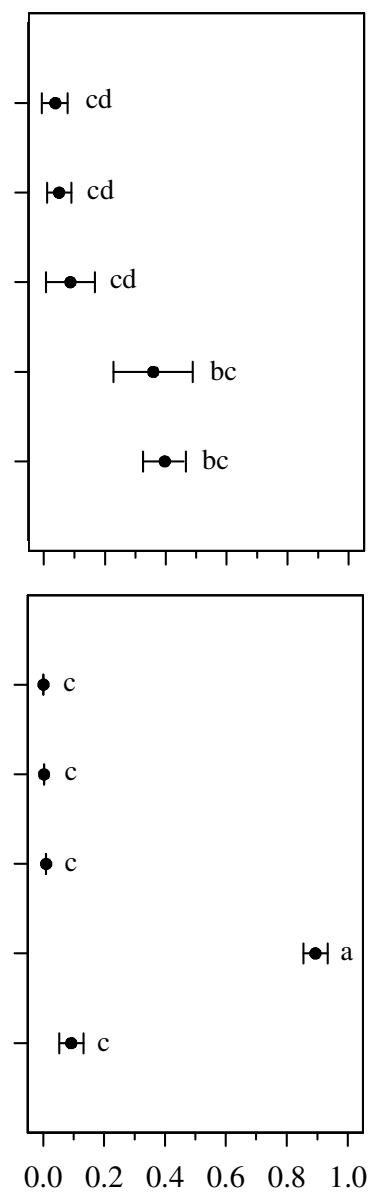

Fractional water uptake
Fraxinus
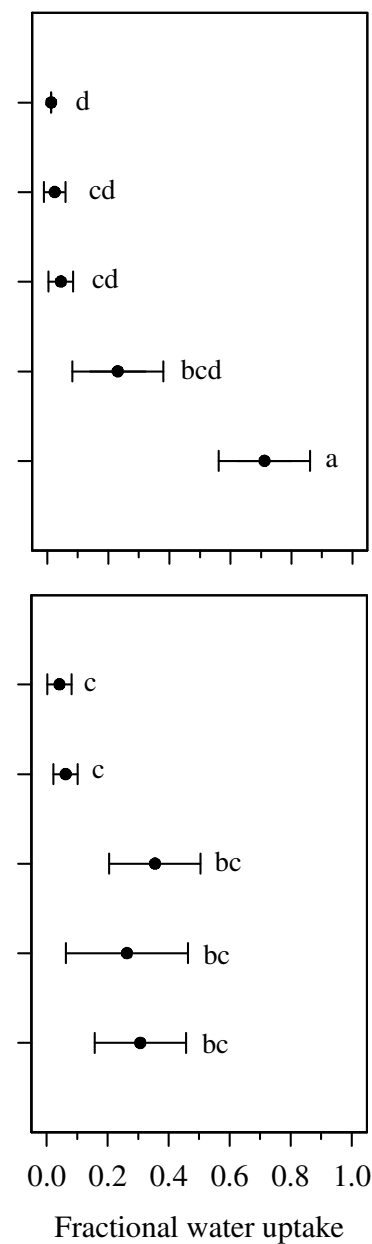

Fig. 5. Proportional $\delta D$ source contribution of the observed soil depth to the mixture (xylem water), expressed as fractional water uptake. Shown are the results for trees in single-species clusters (A) and mixed clusters (B). Values are means \pm sd $(n=12$ for single and $n=4$ for mixed clusters), different letters specify significant differences among species (ANOVA).

which might serve as a buffer for peak demand of water uptake. In contrast, in an Indonesian cacao agroforest, Schwendenmann et al. (2010) found that Gliricidia shade trees, which had larger dbh than cacao trees, used deeper water sources. Here it has to be taken into account that Gliricidia had about double the height of the cacao trees, whereas our trees were very homogenous in height.

In our data set, tree size did however show no effect on the vertical distribution of soil water uptake of trees when located in the single species clusters, despite the similar diameter range compared to the mixed clusters. In addition, in the mixed clusters, there was no particular species dominating in particular tree size (see Fig. 6d). Thus, the relation seems to be independent of species identity, but conditional on the presence of other species as neighbours. No further comparison with the Meinzer et al. (1999) study is possible however, as there was no differentiation between trees with conspecific neighbours or different-species neighbours. The rea- sons behind the strong relation between tree diameter to main soil water uptake depth in mixed clusters and its absence in single-species clusters in our study is ambiguous. It may be influenced by the plasticity in soil water uptake depths of Tilia and Fraxinus growing in single or mixed species clusters as observed in combination with differing dbh sizes.

\subsection{Volume of soil water uptake}

Complementarity in soil water uptake may also lead to enhanced soil water use. For example, in a Panamanian tree plantation, tree transpiration rates increased with increasing tree species diversity, which by way of statistical analysis, Loreau and Hector (2001) suggest to be significant biodiversity effects mainly based on species complementarity (Kunert et al., 2012). There were also indications in the Hainich Forest that mixed stands used more water for transpiration in the beginning of a drought period than 

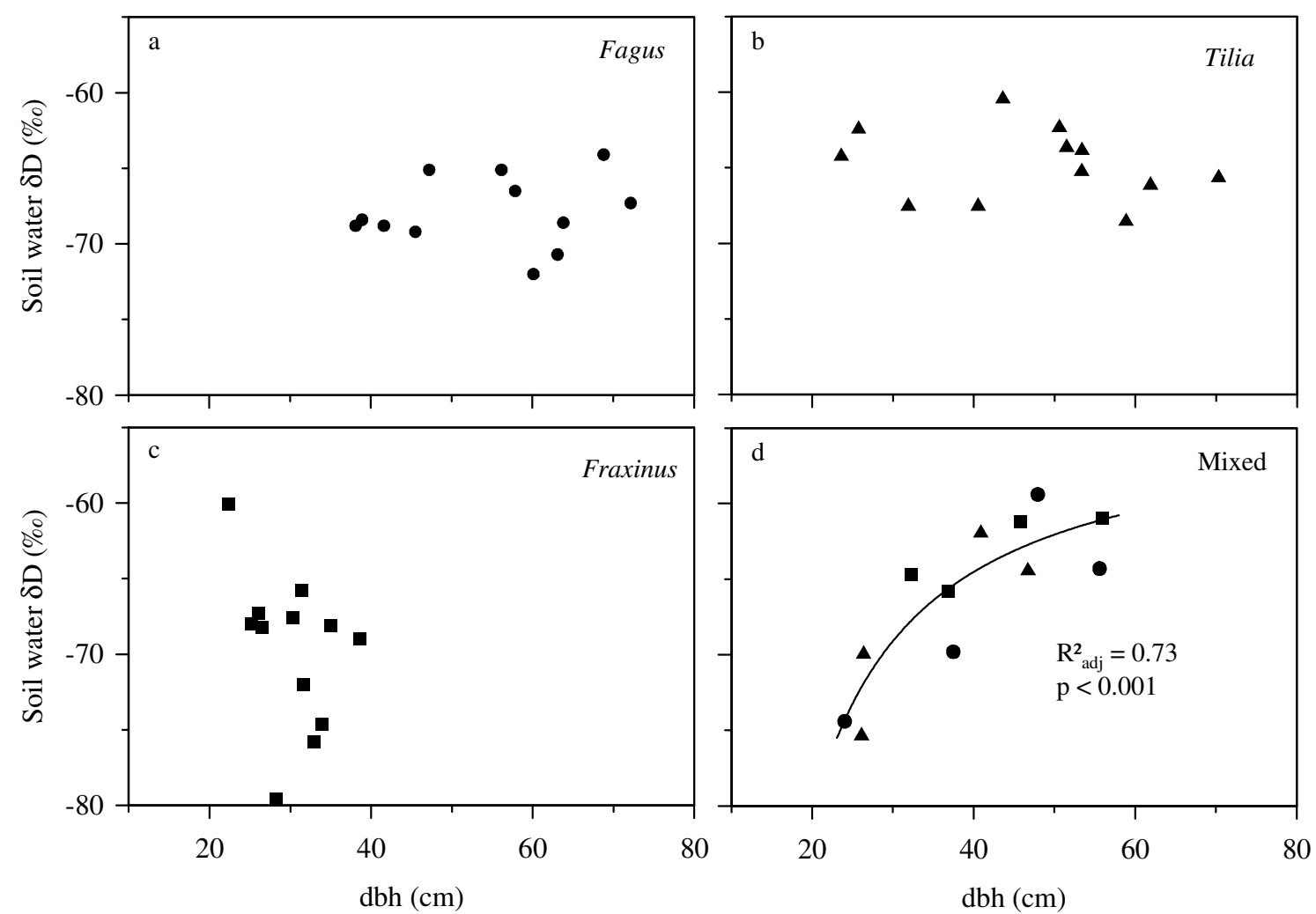

Fig. 6. Soil water $\delta D$ of the main water uptake depth per tree in relation to diameter at breast height (dbh) on single and mixed species tree clusters.

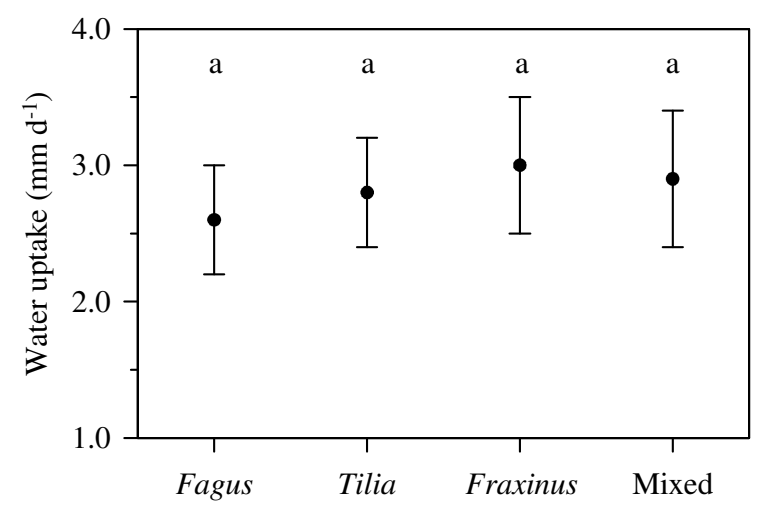

Fig. 7. Estimated water uptake $\left(\mathrm{mm} \mathrm{d}^{-1}\right)$ from 0 to $0.7 \mathrm{~m}$ soil depth during desiccation period from 30 July to 9 October 2009. Measured on single and mixed species clusters composed of Fagus, Tilia and Fraxinus. Values are means \pm sd $(n=4)$, similar letters specify no significant difference between species.

monospecific beech stands (Krämer and Hölscher, 2010; Bittner et al., 2010). Despite the observation of complementarity in soil water uptake depth in the present study, we did not observe statistically significant differences in the volume of water uptake between single- and mixed-species clusters. A possible explanation is that evapotranspiration rates, which have an affect on the volume of water uptake in trees, are controlled by stand structure and can vary with changes in, e.g. aerodynamic roughness. These processes however act at a much larger scale than tree clusters and therefore might cover effects of complementarity.

All our study clusters were embedded in two larger mixed forest stands and thus possible differences between singleand mixed species stands may not have been detected. It may also be argued that the volume of water extracted in the single- and mixed species clusters is the same, but that the expense of water uptake may be different, e.g. leading to altered water use efficiency.

Our study also has implications with respect to forest management in close-to-nature forestry, which is an upcoming practice for temperate broad-leaved forest management. It shows that this practice leads to stands of a wider diameter distribution and it may also enhance tree species diversity. Our data would suggest that a wide diameter range in a single species stand would not lead to a variation in soil water uptake depth. Species mixture hints to complementarity, but our data did not suggest that complementarity leads to increased water consumption. In summary, our results imply that soil water partitioning among canopy trees is strongest where species are mixed and tree size varies. 


\section{Appendix A}

Table A1. Soil texture and soil bulk density of single and mixed species tree clusters. Values are means \pm sd $(n=4)$.

\begin{tabular}{lrllll}
\hline & Soil depth & \multicolumn{4}{c}{ Cluster } \\
\cline { 3 - 6 } & $(\mathrm{m})$ & Fagus & Tilia & Fraxinus & Mixed \\
\hline Soil texture & $0-0.1$ & $2 / 74 / 24$ & $3 / 73 / 25$ & $3 / 68 / 29$ & $3 / 75 / 23$ \\
(sand/silt/clay) & $0.1-0.2$ & $3 / 75 / 22$ & $2 / 74 / 24$ & $2 / 69 / 29$ & $3 / 75 / 23$ \\
& $0.2-0.3$ & $3 / 71 / 26$ & $3 / 75 / 23$ & $2 / 72 / 26$ & $2 / 71 / 27$ \\
& $0.3-0.4$ & $4 / 68 / 28$ & $3 / 67 / 30$ & $2 / 67 / 31$ & $3 / 68 / 29$ \\
& $0.4-0.6$ & $2 / 59 / 39$ & $2 / 58 / 40$ & $2 / 56 / 42$ & $2 / 54 / 44$ \\
& $0.6-0.8$ & $2 / 59 / 39$ & $2 / 58 / 40$ & $2 / 56 / 42$ & $2 / 54 / 44$ \\
\hline Bulk density $^{-3}$ ) & $0-0.1$ & $1.1 \pm 0.2$ & $1.1 \pm 0.2$ & $1.0 \pm 0.1$ & $1.1 \pm 0.1$ \\
& $0.1-0.2$ & $1.3 \pm 0.1$ & $1.2 \pm 0.1$ & $1.3 \pm 0.1$ & $1.3 \pm 0.0$ \\
& $0.2-0.3$ & $1.4 \pm 0.1$ & $1.4 \pm 0.1$ & $1.4 \pm 0.1$ & $1.5 \pm 0.1$ \\
& $0.3-0.4$ & $1.4 \pm 0.1$ & $1.4 \pm 0.1$ & $1.5 \pm 0.1$ & $1.5 \pm 0.1$ \\
& $0.4-0.6$ & $1.5 \pm 0.1$ & $1.5 \pm 0.1$ & $1.4 \pm 0.0$ & $1.5 \pm 0.1$ \\
& $0.6-0.8$ & $1.5 \pm 0.1$ & $1.5 \pm 0.1$ & $1.5 \pm 0.1$ & $1.5 \pm 0.1$ \\
\hline
\end{tabular}
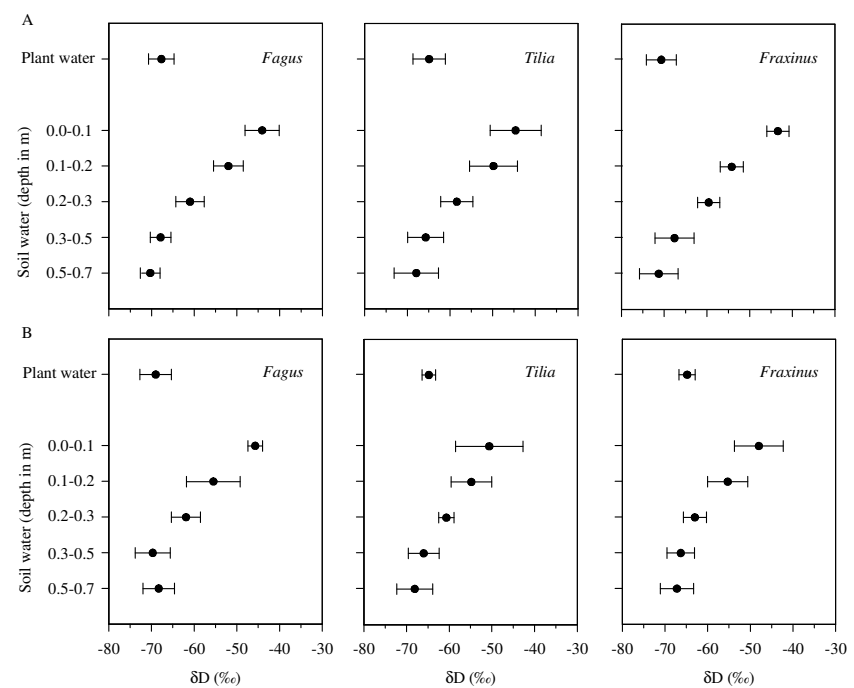

Fig. A1. Plant and soil water $\delta \mathrm{D}$ values for single- and mixedspecies clusters (A and $\mathbf{B}$, respectively). Values are means \pm sd $(n=12$ for $\mathbf{A}, n=4$ for $\mathbf{B})$.

Acknowledgements. This study was conducted within the framework of the Research Training Group "Graduiertenkolleg 1086: The role of biodiversity for biogeochemical cycles and biotic interactions in temperate deciduous forests", funded by the DFG (German Research Foundation). We thank Dominik Seidel, Tobias Wommelsdorf and Christina Langenbruch for providing data on cluster characteristics, the Centre for Stable Isotope Research and Analysis in Göttingen for the valuable cooperation, Kyle Lawson for support during data collection, and Daniel McCluskey as well as the reviewers for critically reading and commenting on the manuscript.
This Open Access Publication is funded

by the University of Göttingen.

Edited by: P. Stoy

\section{References}

Asbjornsen, H., Mora, G., and Helmers, J.: Variation in water uptake dynamics among contrasting agricultural and native plant communities in the Midwestern US, Agr. Ecosyst. Environ., 121, 343-356, 2007.

Bittner, S., Talkner, U., Krämer, I., Beese, F., Hölscher, D., and Priesack, E.: Modeling stand water budgets of mixed temperate broad-leaved forest stands by considering variations in species specific drought response, Agr. Forest Meteorol., 150, 13471357, 2010.

Breckle, S. W. and Walter, H.: Walter's Vegetation of the Earth: The Ecological Systems of the Geo-Biosphere, 4th Edt., Springer Berlin Heidelberg, 2002.

Christensen, J. H., Hewitson, B., Busuioc, A., Chen, A., Gao, X., Held, I., Jones, R., Kolli, R. K., Kwon, W-T., Laprise, R., Magaña Rueda, V., Mearns, L., Menéndez, C. G., Räisänen, J., Rinke, A., Sarr, A., and Whetton, P.: Regional climate projections, in: Climate Change 2007: The Physical Science Basis, Contributions of Working Group I to the Fourth Assessment Report of the Intergovernmental Panel on Climate Change, edited by: Solomon, S., Qin, D., Manning, M., Chen, Z., Marquis, M., Averyt, K. B., Tignor, M., and Miller, H. L., Cambridge University Press, New York, 2007.

DWD (Deutscher Wetterdienst) Offenbach, available at: http:// www.dwd.de, last access: 10 October 2010.

Ehleringer, J. R. and Osmond, C.: Stable Isotopes, Plant Physiological Ecology Field Methods and Instrumentation, edited by: Pearcy, R. W., Ehleringer, J. R., Mooney, H. A., and Rundel, P. W., Chapman and Hall Ltd. London, 281-299, 1989.

Ehleringer, J. R. and Dawson, T. E.: Water uptake by plants: perspectives from stable isotope composition, Plant, Cell and Environment, 15, 1073-1083, 1992.

Ehleringer, J. R., Roden, J., and Dawson, T. E.: Assessing ecosystem-level water relations through stable isotope ratio analyses, in: Methods in Ecosystem Science, edited by: Sala, O. E., Jackson, R. B., Mooney H. A., and Howarth, R. W., 181-398, 2000 .

Ellenberg, H. and Leuschner, C.: Vegetation Mitteleuropas mit den Alpen: In ökologischer, dynamischer und historischer Sicht, 5th Edt., Ulmer Eugen Verlag, 2010.

Gebauer, T., Horna, V., and Leuschner, C.: Variability in radial sap flux density patterns and sapwood area among seven cooccurring temperate broad-leaved tree species, Tree Physiol., 28, 1821-1830, 2008.

Gehre, M., Geilmann, H., Richter, J., Werner, R. A., and Brand, W. A.: Continuous flow $2 \mathrm{H} / 1 \mathrm{H}$ and $18 \mathrm{O} / 16 \mathrm{O}$ analysis of water samples with dual inlet precision, Rapid Commun. Mass Sp., 18, 2650-2660, 2004.

Gonfiantini, R.: Standards for stable isotope measurements in natural compounds, Nature, 271, 534-536, 1978.

Guckland, A., Jacob, M., Flessa, H., Thomas, F. M., and Leuschner, C.: Acidity, nutrient stocks, and organic-matter content in soils of a temperate deciduous forest with different abundance of Eu- 
ropean beech (Fagus sylvatica L.), J. Plant Nutr. Soil Sc., 172, 500-511, 2009.

Haggar, J. P. and Ewel, J. J.: Primary productivity and resource partitioning in model tropical ecosystems, Ecology, 78, 1211-1221, 1997.

Hölscher, D., Koch, O., Korn, S., and Leuschner, C.: Sap flux of five co-occurring tree species in a temperate broad-leaved forest during seasonal soil drought, Trees, 19, 628-637, 2005.

Hooper, D. U., Chapin III, F. S., Ewel, J. J., Hector, A., Inchausti, P., Lavorel, S., Lawton, J. H., Lodge, D. M., Loreau, M., Naeem, S., Schmid, B., Setälä, H., Symstad, A. J., Vandermeer, J., and Wardle, D. A.: Effects of biodiversity on ecosystem functioning: a consensus of current knowledge, Ecol. Monogr., 75, 3-35, 2005.

Huxman, T. E., Smith, M. D., Fay, P. A., Knapp, A. K., Shaw, M. R., Loik, M. E., Smith, S. D., Tissue, D. T., Zack, J. C., Weltzin J. F., Pockman, W. T., Sala, O. E., Haddad, B. M., Harte, J., Koch, G. W., Schwinning, S., Small, E. E., and Williams, D. G.: Convergence across biomes to a common rain-use efficiency, Nature, 429, 651-654, 2004.

Jackson, P. C., Cavelier, J., Goldstein, G., Meinzer, F. C., and Holbrook, N. M.: Partitioning of water-resources among plants of a lowland tropical forest, Oecologia, 101, 197-203, 1995.

Köcher, P., Gebauer, T., Horna, V., and Leuschner, C.: Leaf water status and stem xylem flux in relation to soil drought in five temperate broad-leaved tree species with contrasting water use strategies, Ann. For. Sci., 66, 101, 2009.

Krämer, I. and Hölscher, D.: Rainfall partitioning along a tree diversity gradient in a deciduous old-growth forest in Central Germany, Ecohydrology, 2, 102-114, 2009.

Krämer, I. and Hölscher, D.: Soil water dynamics along a tree diversity gradient in a deciduous forest in Central Germany, Ecohydrology, 3, 262-271, 2010.

Kunert, N., Schwendenmann, L., Potvin, C., and Hölscher, D.: Tree diversity enhances tree transpiration in a Panamanian forest plantation, J. Appl. Ecol., 49, 135-144, 2012.

Lang, C., Dolynska, A., Finkeldey, R., and Polle, A.: Are beech (Fagus sylvatica) roots territorial?, Forest Ecol. Manag., 260, 12121217, 2010.

Leuschner, C., Hertel, D., Coners, H., and Büttner, V.: Root competition between beech and oak: a hypothesis, Oecologia, 126, 276-284, 2001.

Loreau, M. and Hector, A.: Partitioning selection and complementarity in biodiversity experiments, Nature, 412, 72-76, 2001.

LÖWE, Langfristige: Ökologische Waldentwicklung in den Niedersächsischen Landesforsten, LÖWE-Erlass, 2007.

Meinen, C., Hertel, D., and Leuschner, C.: Biomass and morphology of fine roots in temperate broad-leaved forests differing in tree species diversity: is there evidence of belowground overyielding?, Oecologia, 161, 99-111, 2009a.

Meinen, C., Leuschner, C., Ryan, N. T., and Hertel, D.: No evidence of spatial root system segregation and elevated fine root biomass in multi-species temperate broad-leaved forests, Trees, 23, 941950, 2009b.
Meinzer, F. C., Andrade, J. L., Goldstein, G., Holbrook, N. M., Cavelier, J., and Wright, S. J.: Partitioning of soil water among canopy trees in a seasonally dry tropical forest, Oecologia, 121, 293-301, 1999.

Mölder, A., Bernhardt-Römermann, M., and Schmidt, W.: Forest ecosystem research in Hainich National Park (Thuringia): First results on flora and vegetation in stands with contrasting tree species diversity, Waldoekologie online, 3, 83-99, 2006.

Mölder, A., Bernhardt-Römermann, M., and Schmidt, W.: Vielfältige Baumschicht - reichhaltige Verjüngung? Zur Naturverjüngung von artenreichen Laubwäldern im Nationalpark Hainich, Allg. Forst Jagdztg., 180, 76-87, 2009.

O'Hara, K. L.: The Silviculture of transformation - a commentary, Forest Ecol. Manag., 151, 81-86, 2001.

Phillips, D. L. and Gregg, J. W.: Source partitioning using stable isotopes: coping with too many sources, Oecologia, 136, 261269, 2003.

Potvin, C. and Dutilleul, P.: Neighborhood effects and sizeasymmetric competition in a tree plantation varying in diversity, Ecology, 90, 321-327, 2009.

Rewald, B. and Leuschner, C.: Belowground competition in a broad-leaved temperate mixed forest: pattern analysis and experiments in a four-species stand, Eur. J. Forest Res., 128, 387-398, 2009.

Rowell, D. P. and Jones, R. G.: Causes and uncertainty of future summer drying over Europe, Clim. Dynam., 27, 281-299, 2006.

Schaap, M. G., Leij, F. J., and Van Genuchten, M. T.: ROSETTA: a computer program for estimating soil hydraulic parameters with hierarchical pedotransfer functions, J. Hydrol., 251, 163-176, 2001.

Schwendenmann, L., Veldkamp, E., Moser, G., Hölscher, D., Köhler, M., Clough, Y., Anas, I., Djajakirana, G., Erasmi, S., Hertel, D., Leitner, D., Leuschner, C., Michalzik, B., Propastin, P., Tjoa, A., Tscharnke, T., and Van Straaten, O.: Effects of an experimental drought on the functioning of a cacao agroforestry system, Sulawesi, Indonesia, Global Change Biol., 16, 15151530, 2010.

Simunek, J., Van Genuchten, M. T., and Sejna, M.: Development and Applications of the HYDRUS and STANMOD Software Packages and Related Codes, Vadose Zone J., 7, 587-600, 2008.

Vandermeer, J. H.: The ecology of intercropping, Cambridge University Press, Cambridge, UK, 1989.

Van Peer, L., Nijs, I., Reheul, D., and De Cauwer, B.: Species richness and susceptibility to heat and drought extremes in synthesized grassland ecosystems: compositional vs. physiological effects, Funct. Ecol., 18, 769-778, 2004.

Verheyen, K., Bulteel, H., Palmborg, C., Olivié, B., Nijs I., Raes, D., and Muys, B.: Can complementarity in water use help to explain diversity-productivity relationships in experimental grassland plots?, Oecologia, 156, 351-361, 2008.

West, A. G., Patrickson, S. J., and Ehleringer, J. R.: Water extraction times for plant and soil materials used in stable isotope analysis, Rapid Commun. Mass Sp., 20, 1317-1321, 2006. 